\title{
Bahan Ajar Matakuliah Pengelolaan Sumberdaya Alam S1 Biologi Universitas Negeri Malang
}

\author{
Moh. Imam Bahrul Ulum ${ }^{1}$, Murni Saptasari ${ }^{1}$, Suhadi ${ }^{1}$ \\ ${ }^{1}$ Pendidikan Biologi-Universitas Negeri Malang
}

\begin{tabular}{l}
\hline \hline INFO ARTIKEL \\
\hline Riwayat Artikel: \\
Diterima:13-05-2019 \\
Disetujui:15-11-2019 \\
\hline
\end{tabular}

\section{Kata kunci:}

teaching materials; natural resource management; bahan ajar;

pengelolaan sumberdaya alam

\section{ABSTRAK}

Abstract: Aims to produce valid teaching materials in terms of the validation of media experts, material experts, field practitioners, and practically in terms of student responses. The development model refers to the ADDIE model (Analyze, Design, Develop, Implement, Evaluate). Data retrieval using the teaching material validation sheet and student response questionnaire. The results of the validation of teaching materials by the media expert validator was $88.42 \%$, the material experts amounted to $92.35 \%$ of field practitioners as much as $89.13 \%$, and the student response was $86.92 \%$. From the results, teaching materials are very valid or very well used for learning Natural Resource Management subjects.

\begin{abstract}
Abstrak: Penelitian ini bertujuan menghasilkan bahan ajar yang valid ditinjau dari hasil validasi ahli bahan ajar, ahli materi, praktisi lapangan, dan bahan ajar yang praktis ditinjau dari respons mahasiswa. Pengembangan bahan ajar mengikuti tahapan ADDIE (Analyze, Design, Develop, Implement, Evaluate). Pengumpulan data menggunakan lembar validasi bahan ajar dan kuesioner respons mahasiswa. Hasil validasi yang diperoleh dari validator ahli bahan ajar sebesar $88,42 \%$, ahli materi sebesar $92,35 \%$ praktisi lapangan sebesar $89,13 \%$, dan respons mahasiswa sebesar $86,92 \%$. Berdasarkan hasil analisis maka bahan ajar sangat valid atau sangat baik digunakan untuk pembelajaran matakuliah Pengelolaan Sumberdaya Alam.
\end{abstract}

\section{Alamat Korespondensi:}

Moh. Imam Bahrul Ulum

Pendidikan Biologi

Universitas Negeri Malang

Jalan Semarang 5 Malang

E-mail: iemambach14@gmail.com

Peningkatan kualitas pendidikan dapat dicapai melalui peningkatan proses pembelajaran (Suhartoni, Osnal, \& Mahfudz, 2016). Proses pembelajaran merupakan suatu hal yang penting dalam sebuah pendidikan (Nurkholis, 2013) karena interaksi dalam pembelajaran dapat menjadi sarana transfer keilmuan antara pendidik dengan peserta didik yang terstruktur dan terencana (Mukti, 2008) sehingga menjadikan peserta didik paham dengan materi pelajaran yang disampaikan. Peningkatan keefektifan pembelajaran salah satunya dapat dilakukan dengan penggunaan bahan ajar oleh pembelajar sebagai sumber belajarnya.

Bahan ajar memiliki kontribusi tidak sedikit dalam kegiatan pembelajaran (Ellianawati, 2012). Hampir sebagian besar kegiatan pembelajaran di berbagai tingkatan pendidikan menggunakan bahan ajar (Sungkono, 2003). Bahan ajar sangat diperlukan untuk membantu pelaksanaan proses pembelajaran (Pannen, 2001; Zuriah, Sunaryo, \& Yusuf, 2016), dan memperbaiki mutu pembelajaran (Leksono, Syachruroji, \& Marianingsih, 2015). Tanpa adanya bahan ajar, akan sulit bagi dosen untuk meningkatkan efektivitas pembelajaran (Sadjati, 2012). Bahan ajar pada lingkungan pendidikan tinggi wajib disediakan, difasilitasi, atau dimiliki oleh perguruan tinggi sesuai dengan program studi yang dikembangkan (UU RI No. 12, 2012).

Matakuliah Pengelolaan Sumberdaya Alam (PSDA) merupakan matakuliah yang ditempuh mahasiswa S1 program studi Biologi Universitas Negeri Malang. Analisis kebutuhan mahasiswa dilakukan pada mahasiswa S1 Biologi UM yang telah menempuh matakuliah Pengelolaan Sumberdaya Alam (PSDA) diperoleh data bahwa mahasiswa kesulitan memahami materi yang diajarkan sebesar $72,22 \%$. Penggunaan bahan ajar dalam proses pembelajaran kurang bervariasi $83,33 \%$, serta sebesar $66,67 \%$ bahan ajar dinilai kurang memudahkan mahasiswa dalam memahami materi yang diajarkan. Berdasarkan hasil tersebut solusi yang dapat dilakukan yaitu dengan mengembangkan bahan ajar yang sesuai kebutuhan mahasiswa.

Pengembangan bahan ajar perlu dilakukan untuk menjawab atau memecahkan masalah ataupun kesulitan belajar (Zunaidah \& Amin, 2016). Kesulitan tersebut terjadi karena materi tersebut abstrak, rumit, ataupun asing (Ardiansyah, Corebima, \& Rohman, 2017; Jirana, Nur, \& Nurmiati, 2015), maka dari itu untuk mengatasi kesulitan tersebut dikembangkan bahan ajar yang dapat memudahkan mahasiswa dalam mempelajari materi yang dibelajarkan (Zuriah et al., 2016). Beberapa hasil penelitian menunjukkan bahwa bahan ajar sebagai hasil pengembangan mampu meningkatkan hasil belajar (Harijanto, 2007; Setiyadi, 2017), pemahaman konsep (Kurniawan, Irawati, \& Rohman, 2015), sikap siswa (Kurniawan et al., 2015), dan berpikir kritis (Dahlia, Ibrohim, \& Mahanal, 2018; Erawanto \& Santoso, 2016; Kurniawan et al., 2015). 


\section{METODE}

Pengembangan bahan ajar mengacu pada pengembangan model ADDIE. Model pengembangan ADDIE terdiri dari tahapan analyze, design, develop, implement, evaluate (Branch, 2009). Subjek dalam penelitian ini yaitu validator ahli bahan ajar, validator ahli materi, praktisi lapangan, dan mahasiswa S1 Biologi Universitas Negeri Malang. Pengumpulan data dalam pengembangan bahan ajar menggunakan lembar validasi dan kuesioner respons mahasiswa. Analisis data dilakukan berdasarkan hasil perolehan skor dari lembar validasi (ahli bahan ajar, ahli materi, praktisi lapangan) dan kuesioner respons mahasiswa. Pemilihan alat evaluasi menggunakan analisis kuantitatif-kualitatif yang dijabarkan sebagai berikut.

\section{Validasi Bahan Ajar}

Pengukuran validitas bahan ajar dilakukan oleh validator ahli bahan ajar, validator ahli materi, dan praktisi lapangan. Data hasil validasi bahan ajar dianalisis dengan perhitungan sebagai berikut.

$$
\text { Skor Validitas }=\frac{\text { Jumlah skor pada aspek yang dinilai }}{\text { Jumlah total skor }} \times 100 \%
$$

Nilai yang diperoleh dari hasil validitas, kemudian dilakukan pengambilan keputusan berdasarkan kriteria validitas bahan ajar.

Tabel 1. Kriteria Validitas

\begin{tabular}{cll}
\hline \multicolumn{1}{c}{ Kriteria } & Kriteria Validitas & \multicolumn{1}{c}{ Tingkat Validitas } \\
\hline $85,01-100 \%$ & Sangat Valid & Sangat baik digunakan \\
$70,01-85,00 \%$ & Valid & Baik digunakan namun perlu revisi kecil \\
$55,01-70,00 \%$ & Cukup valid & Boleh digunakan namun perlu revisi besar \\
$40,01-55,00 \%$ & Kurang valid & Tidak boleh dipergunakan \\
$01,00-40,00 \%$ & Tidak valid & Tidak boleh dipergunakan \\
\hline
\end{tabular}

\section{Kepraktisan Bahan Ajar}

Pengukuran kepraktisan bahan ajar dilakukan dengan menggunakan kuesioner respons mahasiswa terhadap penggunaan bahan ajar. Data hasil pengisian kuesioner respons mahasiswa terhadap bahan ajar dianalisis dengan perhitungan sebagai berikut.

$$
\text { Skor Kepraktisan }=\frac{\text { Jumlah skor pada aspek yang dinilai }}{\text { Jumlah total skor }} \times 100 \%
$$

Nilai yang diperoleh kemudian dievaluasi berdasarkan kriteria respons mahasiswa (Tabel 2) dan kriteria kepraktisan bahan ajar (Tabel 3).

Tabel 2. Kriteria Respons Mahasiswa

\begin{tabular}{ll}
\hline Respons Mahasiswa & \multicolumn{1}{c}{ Kriteria } \\
\hline $\mathrm{RS} \geq 85 \%$ & Respons Sangat Positif \\
$70 \% \leq \mathrm{RS}<85 \%$ & Respons Positif \\
$50 \% \leq \mathrm{RS}<70 \%$ & Respons Kurang Positif \\
$\mathrm{RS}<50 \%$ & Respons Tidak Positif \\
\hline
\end{tabular}

(Sumber: Diadaptasi dari Yamasari, 2010)

Tabel 3. Kriteria Kepraktisan

\begin{tabular}{lll}
\hline \multicolumn{1}{c}{ Kriteria } & Kategori & \multicolumn{1}{c}{ Tingkat Kepraktisan } \\
\hline $85,01-100 \%$ & Sangat Praktis & Sangat praktis dipergunakan \\
$70,01-85,00 \%$ & Praktis & Praktis dipergunakan \\
$55,01-70,00 \%$ & Cukup Praktis & Tidak praktis dipergunakan \\
$40,01-55,00 \%$ & Kurang Praktis & Tidak praktis dipergunakan \\
$01,00-40,00 \%$ & Tidak Praktis & Tidak praktis dipergunakan \\
\hline
\end{tabular}

(Sumber: diadaptasi dari Akbar, 2013) 


\section{HASIL}

Hasil Validasi Ahli Bahan Ajar

Validasi dilakukan Ibu Dr. Endang Suarsini, M,Ked sebagai validator ahli bahan ajar. Aspek yang digunakan untuk menilai bahan ajar, meliputi kelayakan isi, kebahasaan, sajian, dan kegrafisan. Hasil validasi oleh ahli bahan ajar disajikan pada tabel 4.

Tabel 4. Rerata Skor Hasil Validasi Ahli Bahan Ajar

\begin{tabular}{clccc}
\hline No. & Aspek yang dinilai & Skor yang diperoleh & Rerata skor & Skor Maksimal \\
\hline 1 & Kelayakan Isi & 25 & 4,16 & $6 \times 5=30$ \\
2 & Kebahasaan & 20 & 5 & $4 \times 5=20$ \\
3 & Sajian & 20 & 4 & $5 \times 5=25$ \\
4 & Kegrafisan & 19 & 4,75 & $4 \times 5=20$ \\
\hline \multicolumn{2}{r}{ Total } & $\mathbf{8 4}$ & & $\mathbf{9 5}$ \\
\hline \multicolumn{2}{c}{ Persentase } & & $\mathbf{8 8 , 4 2 \%}$ & \\
\hline
\end{tabular}

\section{Hasil Validasi Ahli Materi}

Validasi ahli materi dilakukan oleh Bapak Drs. Agus Dharmawan, M, Kes. Aspek yang digunakan untuk menilai validitas bahan ajar, meliputi relevansi materi, keakuratan materi, kelengkapan sajian, kesesuaian sajian dengan tuntutan pembelajaran yang terpusat pada mahasiswa, cara penyajian, kesesuaian bahasa dengan kaidah bahasa Indonesia yang baik dan benar, keterbacaan dan komunikatif. Hasil yang diperoleh dari validator ahli materi disajikan pada tabel 5.

Tabel 5. Rerata Skor Hasil Validasi Ahli Materi

\begin{tabular}{|c|c|c|c|c|}
\hline No. & Aspek yang dinilai & Skor yang diperoleh & Rerata skor & Skor Maksimal \\
\hline 1 & Relevansi materi & 41 & 4,5 & $9 \times 5=45$ \\
\hline 2 & Keakuratan materi & 18 & 4,5 & $4 \times 5=20$ \\
\hline 3 & Kelengkapan sajian & 24 & 4,8 & $5 \times 5=25$ \\
\hline 4 & $\begin{array}{l}\text { Kesesuaian sajian dengan tuntutan pembelajaran yang terpusat } \\
\text { pada mahasiswa }\end{array}$ & 22 & 4,4 & $5 \times 5=25$ \\
\hline 5 & Cara penyajian & 20 & 5 & $4 \times 5=20$ \\
\hline 6 & $\begin{array}{l}\text { Kesesuaian bahasa dengan kaidah bahasa Indonesia yang baik } \\
\text { dan benar }\end{array}$ & 14 & 4,6 & $3 \times 5=15$ \\
\hline \multirow[t]{3}{*}{7} & Keterbacaan dan kekomunikatifan & 18 & 4,5 & $4 \times 5=20$ \\
\hline & Total & 157 & & 170 \\
\hline & Persentase & & $92,35 \%$ & \\
\hline
\end{tabular}

\section{Hasil Validasi Praktisi Lapangan}

Validasi bahan ajar oleh praktisi lapangan dilakukan oleh Prof. Dr. Ir. Suhadi, M,Si. Aspek yang digunakan untuk menilai validitas bahan ajar oleh praktisi lapangan, antara lain komponen kelayakan penyajian, komponen kelayakan isi, komponen kelayakan bahasa, kesesuaian dengan sintaks pembelajaran. Hasil validasi bahan ajar oleh praktisi lapangan disajikan pada tabel 6.

Tabel 6. Rerata Skor Hasil Validasi Praktisi Lapangan

\begin{tabular}{clccc}
\hline No. & \multicolumn{1}{c}{ Aspek Penilaian } & Skor yang diperoleh & Rerata skor & Skor maksimal \\
\hline 1 & Komponen Kelayakan Penyajian & 20 & 4 & $5 \times 4=20$ \\
2 & Komponen Kelayakan Isi & 32 & 3,5 & $9 \times 4=36$ \\
3 & Komponen Kelayakan Bahasa & 18 & 3,6 & $5 \times 4=20$ \\
4 & Kesesuaian dengan sintaks pembelajaran & 12 & 3 & $4 \times 4=16$ \\
\hline \multicolumn{2}{c}{ Total } & $\mathbf{8 2}$ & $\mathbf{8 9 , 1 3 \%}$ & $\mathbf{9 2}$ \\
\hline
\end{tabular}

\section{Hasil Respons Mahasiswa terhadap Bahan Ajar yang dikembangkan}

Pengukuran kepraktisan bahan ajar dilakukan dengan menggunakan kuesioner respons mahasiswa. Mahasiswa yang menjadi subjek dalam penilaian yaitu 17 mahasiswa yang telah menempuh matakuliah PSDA. Hasil respons mahasiswa terhadap bahan ajar disajikan pada tabel 7 . 
Tabel 7. Hasil Respons Mahasiswa terhadap Bahan Ajar yang dikembangkan

\begin{tabular}{lcl}
\hline Respons Mahasiswa & Frekuensi & \multicolumn{1}{c}{ Kriteria } \\
\hline $\mathrm{RS} \geq 85 \%$ & 13 & Sangat positif \\
$70 \% \leq \mathrm{RS}<85 \%$ & 4 & Positif \\
$50 \% \leq \mathrm{RS}<70 \%$ & 0 & Kurang positif \\
$\mathrm{RS}<50 \%$ & 0 & Tidak positif \\
\hline
\end{tabular}

\section{PEMBAHASAN}

Berdasarkan hasil validasi bahan ajar oleh validator ahli bahan ajar skor yang diperoleh sebesar $88,42 \%$. Skor tersebut menunjukkan bahwa bahan ajar yang dikembangkan tergolong dalam kategori sangat valid atau sangat baik untuk digunakan. Komentar dan saran yang diberikan, meliputi (1) perlu ada daftar gambar \& daftar tabel, (2) bacaan pada lembar kerja perlu ada sumber dan tahun, (3) kesalahan penulisan nomor tabel, dan (4) tujuan diubah menjadi poin-poin. Saran dan komentar dari validator digunakan untuk merevisi bahan ajar yang telah dikembangkan. Adapun hasil yang diperoleh dari validasi bahan ajar oleh ahli materi sebesar 92,35\%, yang artinya bahan ajar tergolong dalam kriteria sangat valid atau sangat baik dipergunakan. Komentar dan saran yang diberikan, meliputi (1) perlu tambahan kajian teori dalam bahan ajar, (2) materi lebih dijabarkan lagi, dan (3) bahan ajar cukup baik namun perlu sedikit revisi.

Hasil yang diperoleh dari validasi bahan ajar oleh praktisi lapangan yaitu sebesar 89,13\%, artinya tergolong dalam kategori sangat valid atau sangat baik untuk digunakan. Komentar dan saran yang diberikan oleh validator (1) gambar dalam bahan ajar perlu dilengkapi, (2) petunjuk penggunaan dijelaskan lebih rinci untuk mempermudah dosen dalam menggunakannya, dan (3) beberapa ditemukan kesalahan dalam pengetikan. Berdasarkan hasil respons mahasiswa, data yang diperoleh menunjukkan bahwa 13 mahasiswa merespons sangat positif, dan empat mahasiswa merespons negatif. Respons mahasiswa terhadap bahan ajar diperoleh rerata persentase sebesar $86,92 \%$. Hal tersebut menunjukkan bahwa bahan ajar sangat positif atau sangat baik digunakan untuk pembelajaran matakuliah Pengelolaan Sumberdaya Alam.

Bahan ajar memiliki peran penting bagi dosen dan mahasiswa (Leksono et al., 2015). Peran bahan ajar bagi dosen digunakan untuk mengarahkan aktivitas dalam kegiatan pembelajaran sekaligus subtansi kompetensi yang seharusnya diajarkan kepada mahasiswa (Majid, 2012). Dosen akan mengalami kesulitan dalam meningkatkan efektivitas pembelajaran apabila tanpa disertai bahan ajar yang lengkap (Sadjati, 2012). Begitu pula bagi mahasiswa, tanpa adanya bahan ajar mahasiswa akan mengalami kesulitan dalam belajarnya (Jirana et al., 2015). Bahan ajar dalam konteks pembelajaran merupakan salah satu komponen yang harus ada karena bahan ajar merupakan suatu komponen yang harus dikaji, dicermati, dipelajari, dan dijadikan bahan materi yang dikuasai oleh mahasiswa sekaligus memberikan pedoman untuk mempelajarinya (Harijanto, 2007).

\section{SIMPULAN}

Simpulan yang diperoleh berdasarkan hasil dan pembahasan, yakni (1) kelayakan bahan ajar yang dikembangkan berdasarkan penilaian oleh validator ahli bahan ajar, ahli materi, dan praktisi lapangan memperoleh predikat sangat valid atau sangat baik untuk digunakan, (2) kepraktisan bahan ajar berdasarkan respons mahasiswa menunjukkan bahwa bahan ajar sangat positif atau sangat praktis digunakan untuk pembelajaran matakuliah Pengelolaan Sumberdaya Alam. Penelitian pengembangan ini dapat dilakukan dengan melanjutkan uji keefektifan bahan ajar dalam meningkatkan berpikir kritis mahasiswa dan sikap konservasi mahasiswa.

\section{DAFTAR RUJUKAN}

Ardiansyah, R., Corebima, A. D., \& Rohman, F. (2017). Pengembangan Bahan Ajar Mutasi Genetik pada Matakuliah Genetika. Jurnal Pendidikan:Teori, Penelitian, dan Pengembangan, 2(7), 927-9333.

Branch, R. M. (2009). Instructional Design: The ADDIE Approach. New York: Speingger Science Business Medi.

Dahlia, Ibrohim, \& Mahanal, S. (2018). Peningkatan Keterampilan Berpikir Kritis Siswa SMP menggunakan Perangkat Pembelajaran Berbasis Inkuiri Terbimbing dengan Sumber Belajar Hutan Wisata Baning. Jurnal Pendidikan: Teori, Penelitian, dan Pengembangan, 3(2), 188-194.

Ellianawati, S. W. (2012). Pengembangan Bahan Ajar Fisika Matematika Berbasis Self Regulated Learning sebagai Upaya Peningkatan Kemampuan Belajar Mandiri. Jurnal Pendidikan Fisika Indonesia, 8, 33-40. https://doi.org/Doi.10.15294/Jpfi.V8i1.1992.

Erawanto, U., \& Santoso, E. (2016). Pengembangan Modul Pembelajaran Berbasis Masalah untuk Membantu Meningkatkan Berpikir Kreatif Mahasiswa. Jurnal Inovasi Pembelajaran, 2(2), 427-436. https://doi.org/10.22219/ jinop.v2i2.2629

Harijanto, M. (2007). Pengembangan Bahan Ajar untuk Peningkatan Kualitas Pembelajaran Program Pendidikan Pembelajar Sekolah Dasar. Didaktika, 2(1), 216-226.

Jirana, N. S., \& Nurmiati. (2015). Faktor-faktor yang Memengaruhi Kesulitan dan Minat Belajar Mahasiswa Jurusan Pendidikan Biologi Universitas Sulawesi Barat. Jurnal Saintifik, 1(2), 87-94. 
Kurniawan, D., Irawati, M. H., \& Rohman, F. (2015). Pengembangan Perangkat Pembelajaran Ekosistem dan Pencemaran Lingkungan Berbasis Inkuiri serta Pengaruhnya terhadap Kemampuan Berpikir Kritis, Pemahaman Konsep, dan Sikap Siswa Kelas X SMA. Jurnal Pendidikan Sains, 3(3), 137-148. https://doi.org/10.17977/jps.v3i3.8124

Leksono, S. M., Syachruroji, \& Marianingsih, P. (2015). Pengembangan Bahan Ajar Biologi Konservasi Berbasis Etnopedagogi. Jurnal Kependidikan, 45, 168-183. https://doi.org/10.21831/JK.V45I2.7494

Majid, A. (2012). Perencanaan Pembelajaran. Bandung: Rosda Karya.

Mukti, A. (2008). Prinsip-Prinsip Pembelajaran dalam Islam. MIQOT, 32(2), 247-258.

Nurkholis. (2013). Pendidikan dalam Upaya Memajukan Teknologi. Jurnal Kependidikan, 1(1), $24-44$.

Pannen, P. (2001). Penulisan Bahan Ajar. Jakarta: Depdiknas.

Sadjati, I. M. (2012). Pengembangan Bahan Ajar. In: Hakikat Bahan Ajar. Jakarta: Universitas Terbuka.

Setiyadi, M. W. (2017). Pengembangan Modul Pembelajaran Biologi Berbasis Pendekatan Saintifik untuk Meningkatkan Hasil Belajar Siswa. Journal of Educational Science and Technology, 3(2), 102-112. https://doi.org/10.26858/est.v3i2.3468

Suhartoni, Osnal, \& Mahfudz. (2016). Upaya Meningkatkan Kualitas Pembelajaran dengan Pendekatan PAKEM Guru Kelas 4, 5, 6 melalui Supervisi Kelas di SDN 3 Tlogosari Kecamatan Sumbermalang Kabupaten Situbondo Semester I Tahun 2015/2016. Pancaran, 5(1), 105-118.

Sungkono. (2003). Pengembangan dan Pemanfaatan Bahan Ajar Modul dalam Proses Pembelajaran. Majalah Ilmiah Pembelajaran.

Undang-undang Republik Indonesia Nomor 12 Tahun 2012 tentang Pendidikan Tinggi. Jakarta: Kementrian Hukum dan Hak Asasi Manusia Republik Indonesia.

Zunaidah, F. N., \& Amin, M. (2016). Developing The Learning Materials of Biotechnology Subject Based on Students' Need and Character of Nusantara PGRI University of Kediri. Jurnal Pendidikan Biologi Indonesia, 2(1), 19-30. https://doi.org/10.22219/jpbi.v2i1.3368

Zuriah, N., Sunaryo, H., \& Yusuf, N. (2016). IBM Guru Dalam Pengembangan Bahan Ajar Kreatif Inovatif Berbasis Potensi Lokal. Jurnal Dedikasi, 13(1), 39-49. 